INTERNATIONAL JOURNAL OF

MULTIDISCIPLINARY STUDIES ON MANAGEMENT, BUSINESS, AND ECONOMY

\title{
Challenges of Traditional Crafts Centers in Governmental Agencies
}

\author{
Badawi Ismail *
}

Faculty of Archaeology, Luxor University, Luxor, Egypt

\begin{abstract}
Traditional crafts are considered the most important pillar of any country's tangible legacy. In Egypt, some of special properties for traditional crafts that are in each region have its own distinctive traditional crafts that belong to centuries long ago.

Through sequence of periods, these crafts attracted people who are interested in Egyptian legacy, from all over the world. Moreover, there were individual and infrequent attempts resulted in opening markets for those valuable and high quality products. We have seen how Chinese recently affected cultural manufactures field and this expression means what is related to traditional crafts in all over the world. In later titles, we will elaborate in details the cooperation between China and Culture Ministry of Egypt, regarding this point and its shortcomings. Furthermore, we have to shed light on the role of state institutions in protecting traditional crafts and how they promote them, in comparison to the role of civil society institutions in regard to this field. We are going to have a commentary on each following theme, deducing results and recommended solutions.

Keywords

Traditional Crafts.- Jewellery.- UNESCO - Protecting Heritage - Civil Community.
\end{abstract}

\section{HANDIC RAFTS FROM INTERNATIONAL PERSPECTIVE:}

The state wanted to undertake the responsibility of preserving tangible heritage in Egypt, a rich treasure that impressed the entire world, especially after signing agreement of Protecting Diversity and Reinforcing Cultural Expression( 2005)",which is signed by UNESCO."

The agreement has its pivotal role in deepening ways to integrate culture with development policies and honoring the role of culture for achieving the Third Millennium developmental goals, since investing in culture is an investment in sustainable development. Both are aims of Egyptian Government at this time.

During the state of accelerated movement experienced by the Egyptian society and the instability of post-Revolution25 period, variety of Cultural Expression has to be activated, strengthened and protected, at the same time, by Vital Cultural Sectors.

Thus, 2005 Agreement makes a new flexible frame which enables both signatories to do assignments mentioned above: Furthermore, one of the 2005 Agreement pivotal aims is creating an adequate environment to enable cultural work professionals to make culture products, services and activities to help their community and spread them in their surrounding region.

\footnotetext{
*Corresponding author: badawi_16@yahoo.com
} 


\section{Historical Overview of 2005 Convention:}

- "Protecting Diversity and Reinforcing Cultural Expression" has been adopted at Session $33^{\text {rd }}$ of the General Conference of UNESCO, October 2005, and executed at March18, 2007.

\section{Purpose of Convention:}

- Reconfirming that those countries have absolute right in forming cultural policies.

- Recognize that every cultural product has its own nature and means of distinctive identity.

- Strengthen International cooperation and coordination to encourage forms of Cultural Expression relating to each Member States.

- Egypt has signed the Agreement at August 23, 2007 (with an attached file of Member States names).

- 125 countries have signed this Agreement.

- 10 Arabic countries have signed the Agreement, including Tunisia, Jordan, Oman, Kuwait, Egypt, Syria, Sudan, Qatar, Palestine and United Arab Emirates.

\section{Civil Society Role in Protecting Heritage, According to 2005 Agreement:}

Article (1): "the Parties shall confirm the fundamental role of Civil Society in protecting and reinforcing diversity of cultural expression, and shall also encourage parties to participate in Civil Society with effective efforts in achieving aims within this agreement."

About Civil Society activities, the following is mentioned in Chapter of instructive and executive principles of the Convention.

\section{Definition and Role of Civil Society:}

1- Purposes of this Convention, Civil Society means non-governmental organizations, nonprofit institutions, cultural professional and sectors related to it, groups which support artists and cultural communities.

2- Civil Society assumes to carry out a major role in executing this Agreement. Civil society informs Public Authorities about citizens, associations and companies concerns, executes 
programs and plans, observes and warns. Civil Society takes values and creativity into account and adds extra transparency and responsibility to the government.

\section{Civil Society Contribution to fulfill Agreement Terms:}

- $\quad$ Parties shall urge Civil Society to carry out this Agreement by supplying Civil Society wilt appropriate means to draft cultural policies, making information regarding protecting and reinforcing diversity of cultural expression easier to be reached and support Civil Society's capabilities related to it. The Parties may also put special, flexible and effective machineries for this purpose.

- $\quad$ There should be a benefit from the renewed role played by Civil Society and its capacity to be an active part of change, according to this Agreement. Parties shall encourage Civil Society to suggest new thoughts and approaches for establishing cultural policies and to create cultural, innovative programs, processes and activities that contribute achieving aims of this Agreement.

\section{Civil Society may also Take Part in:}

- Supporting the Parties to plan and execute cultural policies.

- Furthering capabilities related to implementing the Convention and collecting data related to protecting and reinforcing diversity of cultural expression.

- Promoting forms of cultural expression by which giving expressing opportunities to people like women and others who considered as minorities and indigenous people, in order to put their circumstances and special requirements into account when formulating cultural policies.

- Initiatives of calling widely for ratifying the convention and calling the government to execute it. Furthermore, supporting the Parties in their efforts to promote aims and goals of the convention in other international forums.

- Contributing in drafting periodic reports of the parties related to their specialization. As a result, this not only will make Civil Society feel responsible, but also will help to increase transparency in those reports.

- Cooperating on local, national and international level for developing Sectors by entering into renewed partnerships, establishing or contributing in it with both Public and Private as well with Civil Society (in other places of the world). 


\section{Civil Society Contribution in the work of Agreement agencies:}

- Civil Society is called upon to contribute in work of the Convention agencies in accordance with the conditions decided by the agencies.

- By virtue of in paragraph of Article (23) of the Convention, the

- Committee may consult at any time the Public or Private Agencies or just common people about specific matters. In this case, the Committee may invite those Agencies to attend a private meeting of the Committee, whether the concerned group or agency has a permission to participate in the Committee sessions or not.

- Civil Society Organizations that are allowed to participate in sessions of Parties and International, Governmental Committee as an observer, according to the inner system of the mentioned agencies, may:

- Inter into dialogue with the Parties about how effectively participate in implementing the Convention. It is preferable as far as possible to do that before holding the sessions of agencies.

- Take part in meetings of these agencies.

- Give views within meetings when they are given the chance by the Head of the concerned agency.

- Provide written contributions related to a work of a specific agency after taking permission of the Head. These contributions are distributed by Secretariat of the Convention to all delegations and observers as they are informative documents.

- Civil society takes part in International 1 Fund for cultural diversity.

\section{Article (15) of the Agreement:}

"Parties shall encourage partnerships between Public and Private Sector, Non-Profit Organization Sectors and within each sector, in order to cooperate with Developing Countries and strengthen their ability to protect and promote diversity of cultural expression. In response to the noticeable needs of the Developing Countries, these partnerships have to focus on continuation of developing human resources, infrastructure and policies and exchange of activities, goods and cultural services."

About the Article, the following is mentioned in Chapter of Instructive and Executive Terms: 
- Partnerships are volunteering mechanisms that aim at cooperation among many institutions, including: Public Authorities (local, national and international $\}$ and Civil Society, including also: Private Sector, the Media, academic community, artists and artistic groups ....., connected with components of society. These mechanisms have risks and benefits which are common among partners and working methods, and so on. For instance, they all agree about making decisions and allocated resources.

- Successful partnerships are based on essential principles which are fairness, transparency, sharing benefits and responsibility, and integration.

- According to article (15), partnerships shall submit to the needs of Developing Countries of the Convention:

- The role of these partnerships is to concentrate as far as possible on the existed and potential agencies and systems, gathering Public Sector with Civil Society, including nongovernmental organizations, non-profit organizations and Private Sector.

It is stated, In Chapter of Instructive and Executive Terms, in Article (19) which concerned with exchanging, analyzing and distributing information that:

\section{Civil Society Participation:}

- $\quad$ Active Parties should take part in Civil Society as they are giving and distributing data and information.

- $\quad$ Civil society Organizations all over the world are called for establishing collaborating relations with each other, on the international, regional and non-regional level. Their activities have to be known by the Secretariat.

To guarantee promoting and producing the Convention, Civil society plays its role:

Under Article (11), concerned with Civil Society participation, and according to instructive and executive principles stated in the Article, Civil Society is called upon effective participation to produce and promote the convention by conscience, cooperation, and coordination with concerned authorities.

Moreover, in accordance with Article (8) of the Convention there are many indications of protecting products, cultural services and different forms of threatened cultural expressions, setting up national, local and regional markets(and supporting them),besides international markets, and allowing other kinds of appropriate contributions. 


\section{Commentary:}

The agreement, that is previously mentioned, is theoretical content which is possible to work upon according to the environment of every country and the characteristics of its traditional crafts.

However, what is attracting attention is concentrating on the importance of civil society role to keep these crafts from dying out and hand over its experiences to the next generation, last these crafts disappear by the dying of their proficient masters.

In this commentary we have to touch. On the ideal way, in our view, towards peaceful treating in this regard with the organizations of the civil society. We can outline it in the following:

Enumerating all civil associations that work in the traditional crafts and collecting whole data about its activities and financing.

- Supervising the role of these institutions and their importance by the experts of analyzing data and statistics.

- Putting recommendations for collaborating between the state institutions and these organizations according to specific analysis .For instance, working in partnership or recourse to the experiences of civil associations in cooperating with specific official institution that lack of this experience and they can get better results together.

- To do that, the civil society cooperates with the state institutions as follows, for example but not limited:

- Organizing symposiums and forums on all levels .This allows the craftsmen, who work in faraway places, to have a role and be apparent.

- Preparing reports and publishing it for clarifying the importance of traditional crafts and its history.

- Publishing information by the national media, its webs, on the internet and its bulletin.

\section{TRADITIONAL CRAFTS CENTER IN FUSTAT:}

\section{Historical Overview:}

1985:

The ministry of cultural assigned the departed artist and the master of potters Saied Al- 
Sadr to establish a center for ceramics in Alfakhraniuh land, Masr Alkadema. He supervised the establishing this center in the form of small atelier that contained only one oven to burn the ceramics

- He has given a wonderful model through this rare trail by limited abilities. 1995:

The cultural ministry decided to develop, rebuild, and provide this center with the equipment and modern oven.

1996:

Building projects started over an area up to 24000 square meters.

2001:

Opening the traditional crafts center in Fustat, that was designed by the engineer GamaI Amer .He is one of the most superior student in Hassan Fathy School .The center was appendage of the visual arts sector then it became appendage of the cultural development fund.

Sections of the Traditional Crafts Center:

- $\quad$ The copper

- $\quad$ The stained glass with gypsum

- $\quad$ The patchwork

- $\quad$ The carpentry

- $\quad$ The jewelry

\section{Commentary on Role and Shortcomings of the Center:}

Firstly: Laborers who carries out the crafts in the center, and quality and quantity of production:

The most important problems which faced the producing governmental sectors are that the producing is not related to incomes and the fixed salaries for the labor. The traditional crafts center suffers from this matter, whereas the craftsmen work in exchange for fixed salaries and get little bonus that is resulted in:

Little quantity of products. 
- Low quality of products, especially its final form.

- $\quad$ There is no interest to deliver this handicraft to the next craftsmen.

\section{Secondly: Inferiority feelings in front of the graduates of prince Charles School:}

The Cultural Development Fund has signed a cooperation protocol with the Prince Charles School for legacy crafts. The school gave to a group of youth a training program about the basis of design in a collection of the traditional crafts which the center interested in them, and then the youth got a certified certificate from the school.

Unfortunately, the center is divided between the school and its administration, so the craftsmen see their counterparts get salaries that is doubled. In addition the discrimination between the two sides, because the representatives of school had high culture and good experiences.

\section{Thirdly: students of Prince Charles School attend for not artistic purposes:}

Most applicants for the Prince Charles School their aim is to take a leisure time in their jobs while studying at the school, with permission of the school administration. Furthermore, they get a monthly reward, knowing that it is somewhat little but the employees who get low salaries are concerned with that reward.

\section{Fourthly: There is no benefiting from the graduates of school:}

Few students attended the private courses; however, there was no benefiting at all from a lot of students. It had to build a design department provided with modern techniques that allow the labor to contact with the specialized international institutions then learn from these experiences and implementing it by using Egyptian designs lest the design of products are not related to Egyptian identity with its traditional feature.

\section{Fifthly: Disappearing the international quality standards:}

The experiences of craftsmen in the traditional crafts center do not treat with international quality standards such as the producing, final conformation and packaging. This is important matter. Some think that they can turn a blind eye but these details are considered the most important things to attract the customers and the most effective factor in universal exhibition. 


\section{Sixthly: Marketing weakness on the local and international level:}

The traditional crafts center participates with its own products few local exhibitions. Which NGOs and official organization also participate in it, and what is attracting attention is the following:

- $\quad$ The center does not participate in one of the greatest craft exhibition that is held in conferences hall, in Egypt at November of every year.

- The exhibitions are held inside the center that is a faraway place; as a result the salability is extremely weak. However, there is more salable in the places that are appendage of The Cultural Ministry, such as the Egyptian Opera squares.

- There is no admitting that recourse to the Marketing Companies from the private sector is important there has to be legal solutions for forming this partnership that should be discussed on a high level; especially the cabinet is paying attention to this matter.

- There is no cooperation with sale store that is located in the airports, hotels and the throng of tourists.

- There is no enough publicity in foreign languages. There has to be cooperation with local and foreign tourist companies.

Subtotal absence from international arena:

The most dangerous problems, that faced the center during participating in the international exhibition, are the following:

- Traditional crafts center in Fustat depends in consigning their products upon foreign cultural relations sector. The budget of this sector is for diplomatic bags only.

- It is stipulated in diplomatic bag system that every bag has to go in and out with the same number, sort. None has to be changed, modified, added to it nor decreased.

- This cause to participate in exhibition only for show not sale.

- This also makes the labor want to travel to these exhibitions for getting substitution for traveling not for advertising these products nor signing package that could be sent after returning to homeland with cartage on account of the buyer.

- Here we should mention Egypt-China year which was carried out on a high level by 
the presidents of the two countries .Egypt was invited to participate in one of the greatest exhibition of cultural industries all over the world. The cultural ministry was afraid of paying shipping costs as products for sale, so the ministry satisfied with transporting by diplomatic bag which had been caused to lose a good opportunity for international marketing.

On the other hand, the agreement dictated The Cultural ministry as a representative of Egypt to invite the official institutions and Chinese private companies that is specialized in traditional crafts but the ministry satisfied with an exhibition had been established inside the Traditional crafts Center in Fustat. Although the exhibition was a high quality in terms of equipment, there were Chinese representatives only from state organization. The exhibition was not popular; especially it was established after the exhibition of international handmade products that has been established by some days in Almaared land.

The Environmental Crafts Organization in The General Institution for Cultural palaces

It is supposed that the general institution of cultural palaces easily able to be in touch with the traditional crafts masters in the places that are fare away, because there are cultural palaces almost in all cities and centers of the provinces. .

The Environmental Crafts Administration is appendage of the Central Administration for Cultural palace. The General institution holds exhibitions in many provinces which include samples from the traditional crafts. Unfortunately, the products do not rise to the level of craftsmanship and cleverness and there are no technicians for supervising, as a result the crafts and its products still as its condition neither developing nor correcting errors.

\section{Cultural Palaces Are Specialized in the Environmental Crafts:}

The cultural palaces institution had established cultural palaces in Kafr Alshrfa that is specialized in the environmental crafts. We cannot deny that are activities held in this palace but they still formal activities not deep and the most important thing is that they cannot recognize this Egyptian legacy which exist in homeland over the country.

Interesting in The Environmental Crafts on A High level but.....

In 2014, the prime minster Ibrahim Mahlab interested in the economics of traditional crafts. He opened actually the traditional crafts celebration that was organized by the general institution for the cultural palace.

The general institution showed the products of civil associations which are specialized in high quality products in addition to works of some outstanding artists so the condition remains as it 
is.

\section{Atlas for the Environmental Crafts:}

The high committee for folklore finished preparing field and geographical encyclopedia for pottery craft which was financed by UNESCO organization. It takes five years.

The encyclopedia contains history of pottery in all its forms which Egypt and Egyptian hand are specialized in pottery since ancient ages. Beginning from Alfakhora, that is the place of making pottery .This spread in Aswan and Qena where a piece is fired after making. The tire is basic tool in pottery and it was found in the same form in pharaonic inscription and the types of mud which is obtained from the Nile, canals, and agricultural land. This documentation is considered extremely important matter to keep Egyptian history in this field but it is better to execute this project to revive what is wiped out and documentation mentioned it.

\section{Commentary:}

Those who observe the efforts of the General Institution for cultural palaces in the environmental crafts field find out that its efforts are dispersed and its interesting in form by effect on quality. For proving, these crafts activities related to folklore groups that are appendage of the general institution which also works apart from original folklore in Egypt.

Strangely, these efforts are not collected under one umbrella although they are in one institution. They also do not depend on scientific facts nor recourse to academic experts for blending skill with scientific facts for design and implementation.

The Central administration for technical production center That is appendage of visual arts sector.

\section{This administration heads:}

- $\quad$ The art and life center.

- Drawing textile center Alghory agency.

\section{Firstly: The art and Life center:}

According to goals that are previously mentioned, its role depends on looking into the identity 
of original Egyptian character, relating the art to the life in every daily aspects of our life, in addition to searching and studying in different arts such as ancient Egyptian, Coptic and Islamic, but these studies should be from the nature whereas the artistic works express the features of Egyptian character.

The center departments are (textiles printing- the Glass department- artistic education department- Embroidery, weaving and fashion department).

\section{Commentary:}

The center contains a group of labor who submit to functional arrangement and upgrading according to the seniority and this leads the center to another way. The center lacks of human resources which managed to do what is mentioned above.

\section{Drawing textile center:}

The aim of the establishment of drawing textile center is revival of the drawing textile heritage and arouses it again, to be of a genuine Egyptian character and to create an Egyptian school has its own style and its special character. On the other hand, this integrates with the orientation to the re-implement of the modern artists' paintings by the weaving on hand-looms, link between the contemporary, originality and prevalence of the creativity of modern arts through a relevant factor of their heritage.

The center holds exhibitions for modern artists work which done with professional textile technique and other modern works of great artists of specialized faculties print and textile, in order to mix academic study and manual crafts together.

\section{Commentary:}

There is no doubt that the center is considered an important position to show the history of contemporary Egyptian art in textiles field but these works remain only in this center where is located on the outskirts of Cairo in Helwan, therefore the visitors numbers decrease and there are no new activities attracted visitors as a result, the center turns to be silent, dead place.

\section{Alghory Agency:}

Alghory Agency and its ritual had stayed as a luminous artistic light, until the mid-nineties of 
last century. The activities of Alghory Agency had stopped when it entered a restoration stage. When the restoration stage had finished, the agency converted to a creativity center as an appendage of the Cultural Development Fund, besides its hosting to Al Tannoura Troupe to make their show three times a week. The center of Alghory Agency, as one of artistic centers that interested in heritage crafts, turned to something like a store for these works which does not have any activity but once a year when a festival is held for its products.

It is worth mentioning that this agency located in one of the most important districts of Cairo, and the most visited on both local and foreign levels. It is situated next to Alazher district and Mezemar Alhosen.

The location of the agency has never been exploited, so it is added to the other places that crammed with employees who do not work neither produce. This is very clear, but is not approved to be talked about, fearing terrorism of the employees, that increased in recent years.

\section{Consequences of the previous problems:}

- Accumulation of production without outlets.

- Centers of Ministry of Culture are turned out to be just a place for employees who do not work.

- There are no incentives for the employees by linking the income with the production and sales.

- The center turned into a routine means that provides products with incomplete specifications.

- Ending the rings of some professional workers in some crafts by reaching the age of retirement or by death.

- In the end, the revenues that help to develop and modify processes have been dropped.

\section{Increased costs and fallen revenues:}

Despite the large impairment of the center's revenues of its products, the second stage of the center's building program has been started. This stage requires a great budget, regardless of marketing and comparison of accounting between costs and revenues. 


\section{Lack of interest in the importance of documentation and scientific research:}

A specialized center of traditional crafts led by the Ministry of Culture, Supposed to have a documentary archive for these crafts, their skillful artisans, history of crafts and what developments occurred through the ages. As well as, these documents should be available with many languages to help scholars and interested people from all the world. Also, it is necessary to make a research competition on this field to encourage the specialists to make scientific researches revealing aspects of art and originality that mark traditional crafts in Egypt.

\section{Solutions:}

We can get practical solutions for all the marketing problems mentioned above by the following proposals:

- Issuing a ministerial decision to modify the rules of Cultural Relations sector, that order to limit consignment costs to only diplomatic bags and exclude traditional crafts exhibitions from this item.

- Establishing outlets in local airports like Luxor, Aswan, Sharm EL- Sheikh and Hurghada.

- Exploiting important, national and international occasions to make exhibitions for the handmade products such as New Year Holiday.

- Signing an agreement with international marketing companies to promote the handmade products out of Egypt.

- Using experts at international quality standards.

- Assuming the main role of Cultural Development Fund which interested in craftsmen, who have microenterprise, to help them and market their products and document their heritage.

- $\quad$ Establishing Egyptian Heritage Research Center for Traditional Crafts including all the information mentioned above.

- Making effective frame works for cooperation between the center and the specialized colleges in the field of pottery and other related fields.

- $\quad$ Exploiting the state of international sympathy with Egypt at this stage to make exhibitions of traditional crafts in Arab capitals as [Dubai, The United Arab Emirates, Kuwait and Manama]. These exhibitions may be done as consecutive round from capital to another to save the expenditures. 
- Reconsidering cooperation with Prince Charles School, evaluate the impacts and seeking to find the best recommendation of English Organization, that will benefit the crafts industry in Egypt.

- Trying to arrive at an agreement with the Ministry of International Cooperation, which can make successful international agreements for marketing the products of craft; especially under the present state of ministerial changes.

- $\quad$ Reconsidering the project of "get a beautiful craft" which gives an opportunity for those who want to work on a craft. Whereas, without this project there will be no chance for them to establish productive small business which is the most important point. This could possibly be done by agreement with the Social Fund or with one of the National Banks.

\section{The Ministry of Industry and Protecting Traditional Crafts:}

The Ministry of Industry has established the industrial technology centers which include:

- Jewelry technology center.

- $\quad$ Fashion and design center.

- Cleaner production technology center.

- The clean technology in tanning processes.

- Plastic technology center.

- Leather technology center.

- $\quad$ Center of improving quality and increasing production.

- $\quad$ Food technology center.

- Textile technology center.

These centers supposed to aim at a connection between the applied researches and industrial researches, and take advantage of scientific and industrial infrastructure, as well as helping small and medium industrial companies. We will touch on some activities of these centers, its pros and cons at the following: 


\section{Firstly: The Jewelry Technology center:}

This center organizes training courses in fields of designing, forming jewelry and installing gemstones for the technicians and worker in factories, workshops and jewelry companies by Egyptian and foreign specialized experts. The purpose of these courses is progressing the level of technicians and workers' productivity, and developing their skills. As well as, training them on the recent international specialized programs and creating skillful technical cadres in this field.

\section{Prime Project:}

The jewelry technology center has established Prime project or the encouragement of education through the generations in the field of gold, silver and gemstones; under patronage of European Union. The project has been managed by Italia through the Romanian institution of traditional crafts [Erty]. The purpose behind this is keeping these professions from extinction.

The project started in Alexandria Governorate then moved to Cairo.

Training and learning processes continued for a whole year and resulted

in training 15 young men and women, whose ages are not over 35 years. At the end of project, the trainees exhibited some works inspired by Egyptian heritage [Coptic, Pharaonic, Islamic, or folkloric].

\section{Commentary:}

Jewelry Technology Center plays an important role in modernization of jewelry industry techniques in Egypt; of course it is a good matter.

Also, the center can use international experiences in this field and get support to organize these training courses, however we can note the following:

1. The center, like important projects in Egypt, is paid more attention but the other parties are neglected. This is evident in Prime project which restricted to be in Cairo and Alexandria. This means that we are losing gradually a big number of skillful craftsmen in this field who live in other regions of Egypt and do not get any attention.

- The Jewelry Technology Center uses modern equipment and machines, although it does not play a role to find a solution to

the problem of importing these equipment with customs facilities for the owners of jewelry 
workshops. This is why the workshops are out of competition; they lost the international quality standards.

- The center proceeds, in one direction, with organizing high- standard exhibitions in terms of product and the target groups of this product. Thus, the Center creates a barrier between the actual industry and the manufacturers whose wages vary depending on each industry centers.

- Gold Market has skilled laborers, who are trained in a scientific and professional way. But the Jewelry Technology Center could not fill the gap in this field; although it was possible to do that for money to train the others and spending on equipment and services.

- Jewelry market in Egypt has dominated by a specific group of names and companies. However, The state gives them a wide space them without entering into a real competition.

- The state does not support many of local and international exhibitions concerned with Egyptian jewelry products. In spite of the products' characteristics, in the terms of heritage design, they remained stereotyped without much renewal. So, the jewelry designers who have dominated the market could impose one style and form to become common.

\section{Solution:}

1. Establishing small projects for graduates of technical colleges and professional diplomas in collaborating with the Ministry of Education, Ministry of Higher Education and Ministry of Industry and Trade. This project will be responsible for producing new creativity on the level of design, and skilled technicians in the field of industry.

- Make a coordination with the Ministry of Antiquities for holding a jewelry exhibitions inspired by the ancient Egyptian history with all

its different ages besides all exhibitions antiquities held all over the world.

- $\quad$ Make a coordination with the Fashion Center to train models to do jewelry products show. This problem was actually experienced through an exhibition organized by the Ministry of Culture.

- The jewelry Technology Center should connect between training and the market needs; and provide suitable job opportunities for trainees; instead of losing theme in the midst of the details related to the work in Egypt. 
- Going out of the capital and deepening into various parts of Egypt; that have a lot of human and artistic treasures.

\section{Secondly: The Textile Technology Center:}

A company has been established under patronage of Textile Industry Technology. It is a joint company with Egyptian and foreign capital (Joint Venture) according to the investment law N0.8 of 1997.This Company is an independent service company managed by a group of businessmen and industrialists. Also this company endeavor to modernize textile industry and readymade Garments by elite of Egyptian and foreign experts.

As well as, the company provides many services, like:

- $\quad$ Providing experimental units to train the factory workers.

- Giving integrated training programs to raise the level of textile industry workers.

- Providing with techniques and mechanisms of modern technology; to develop the ways and methods of production.

- Helping establish laboratories of testing and quality, and training its workers.

- Contributing in development of products and making designs according to the international taste.

This company is a successful model. It is characterized by combining the capacity of the State, in terms of systems and laws, with the capacity of Private Sector, in the terms of flexibility of the measures and upholds the principle of profitability. However, in the recent years, the company faced many of obstacles. The most important are:

- Abolition of the Special Free Zones, which leads to reluctance of many investors.

- The negative impact of international factors like the economic crisis of Europe, the decline in demand rate in American than usual, rising the production costs, and the sluggish administrative system. This affected the growth of industry and export rates. As well as, the decline rate of exports has ranged since 2012 between 3-4\%, but it increased in 2016 to 13\%, according to formal announcement.

- The instability of foreign currency rates and the competing with Chinese, Turkish and Syrian exports; in addition to smuggling. 


\section{Commentary:}

- The Ministry of Industry could not affect on the Ministry of

Investment to discuss the consequences of abolishing of the Special Free Zones and put new articles to attract the investors to the field of textile.

- The necessity of making the required measure to protect the Egyptian product during the domination of many products coming from many other countries, spite of the fact that the Egyptian product is distinguished and unique.

- $\quad$ The needing to provide incentives for the graduates of technical colleges to work in this field.

- $\quad$ Although, there are many signed agreements with various countries and international organizations, the impact of these conventions is very weak for the local production.

- The absence of quality standards is one of the main reasons for entrance of the foreign products in competition with the Egyptian products.

\section{Solutions:}

- dependence on local manufactured fabrics.

- Discounting transportation costs by depending on the local industry.

- Offering facilities on loans to stimulate the 'producers.

- Imposition strict conditions with regard to import of textile from outside.

- Interference in solving the problems that faced the local factories, and putting appropriate solutions. The State shall provide these consultations at no or nominal charges for these factories.

- The State shall enter the Marketing Course on the International Level, through Trade Agreements and select modern promotional methods. 


\section{Thirdly: Fashion and Design Center:}

The Fashion and Design Center is distinguished of being one of centers that give up the administrative bureaucracy and managed to promote collaboration with international specialized centers .The center cooperated with Burgo Fashion Institute, one of the fashion institutes in Milano- Italy .This experience received great request from those who interested in the occupational specialization in fashion and design .On the other hand ,there is a cooperation between the Fashion and Designs center, and the German Arabic Chamber of Commerce and Bazar Berlin .

Allaga is a remarkable trade mark in the fashion in Egypt today.

It based on a team-work for a group of Egyptian designer youth to produce modern fashions inspired by the Egyptian Heritage and from Egyptian Materials 100\% of cotton and linen .In addition to designs of legacy crafts like embroidery of Siwa and Sinai and the Upper Egyptian manual fabrics.

It is important to consider this center one of the successful governmental models to a great degree in offering products depended on the Egyptian Identity and presenting them in a modern style.

\section{Commentary:}

- However, the success that mentioned above, there is a great neglect for some of the distinguished characters of the Egyptian products in designing. For example ,but not limited ,Eltally Clothes that marked Assut 'villages and dazzled the world by their style and quality .But they did not receive the State's attention which make them susceptible to obliteration .

- Dependence on producers who interested in nominal dazzle and neglecting craftsmen who interested in details, which leads to increasing the demand for purchasing .

Lack of recourse to experts in the history of product, its rarity and its emerging factors .If those write down on the product, the matter will become more profoundly and seriousness.

\section{General Commentary on These Centers:}

It is important to strengthen those who in charge of these centers and their extreme ability to highlight the Egyptian crafts. But:

Why these activities centralized only on Cairo and Alexandria, without the other governorates?

Why there is not assigned to researchers, to study the distinguished characters of the clothes in 
the Egyptian Provinces that beyond the circle of attention?

Why there are not workshops and training courses held with the gaffers of these crafts .Particularly from the people of poor villages, who need support to develop their infinitesimal projects?

Why the ministry of industry does not hold a general conference with the civil associations that work in the traditional crafts in Egypt. To discuss the prospects of this cooperation and face obstacles that reduce the role of these associations?

\section{The related Research Institutes:}

"Tamayuz Center for Technologies and Products of Innovation Textile "in the National Center for Researches.

The research activity of the textile industries in the National Center for Research has begun since 1959 under the name of Dyeing and Painting Unit.In 1961 the textile chemistry unit was established. As a result to the continuous development in this field and availability of specialized capabilities, the four workshops specialized in the engineering of spinning and textile ,protein and industrial fiber, cellulose fiber and dyeing, printing and intermediate materials were established in 1981. Since the issue of the Revised Regulations of the National Research Center in 1988,these workshops were converted into five sections :

- $\quad$ Spinning and Textile Engineering Section.

- $\quad$ Preparation the Cellulose Fiber Section .

- $\quad$ Protein and Industrial Fibers Section.

- $\quad$ Typing, Dyeing and Intermediate materials Section.

- $\quad$ Research of Ready-made Clothing and Tricot Section.

The Academy of Scientific Research and Technology has concerned with researches that specialized in the textile industry development in Egypt. It funded many research projects to advance this industry

, through Science and technology fund programs . One of these projects is "Tamayuz Center for Technologies and Products of Innovation Textile ".

The aim of establishing this Center is to progress the results of researches that have been 
obtained on a laboratory level to a half industrial level (and making a model to the product ):

\section{Related colleges and technical schools:}

Of course, Faculties of Applied Art, Fine Arts and some departments of Art Education and Specific Education Faculties, consider laboratories to graduate academic qualified youth ,To join labor market that concerned with some crafts and developed them properly. Especially in the areas of: pottery, textile, carpentry and fashion design .I the same regard, the technical and vocational rehabilitation institutes and schools, also providing outstanding skills of workers in these crafts .

\section{CONCLUSION:}

\section{From what mentioned above we can notice that:}

- $\quad$ The State Agencies, that interested in the traditional crafts, working apart from each other .This is also, occurred in the single ministry and sometimes in the single sector or organization.

- If the financial allocations of each agency, unit or administration

, of those mentioned above, are collected together, they will be enough to establish a national project for keeping and developing the traditional crafts.

- However, the high unemployment rate, there is not a human resources exploitation. Whereas many of those who seeking for jobs opportunities, can practice these crafts.

- Wastage and dispersion of these efforts eliminated these crafts from being an important source of investment and increasing exports.

- This dispersion in.th.is activity makes the responsibility distributed which every sector lay the blame on the other.

- The possibilities that are provided by the Administrative Agency of the State and the specifications of the private sector should be combined.

- Although the Ministry of Culture assumes the responsibility of documentation and keeping origin of these crafts, these isolated agencies do not serve these goals at all.

- With all appreciation to the Researches Center's efforts. But the scientific research that leaves on the shelf without implement does not contribute in the desired development process.

- Surely, the absence of economics and feasibility studies from the heads of the state 
agencies that worked in this field, eventually leads to infinity costs and much lower financial returns most of them distributed to employees bonuses.

- There are an exploitation from some of the rich in Egypt .They product deformed copies of these crafts and make them prevalent in the local market as well as ,large part of the global market .This effects on the profound and authentic products .

\section{RECOMMENDATIONS:}

The National Organization for Keeping and Developing the Traditional Crafts:

- A national organization appendage of the Council of Ministers shall be established, to keep and develop the traditional crafts.

- Chairman of the board shall be the president of the Council of Minister. The Council in its membership shall include the Minister of Industry and Trade, Culture, Finance ,Investment, Higher Education, Vocational Education or Education.

- Law shall be drafted to this organization, to ensure that it will have a special nature for the financial and administrative procedures.

- A group of joint-stock companies that specialized in the related crafts, shall be established under the patronage of the organization.

- The organization law shall ensure customs releases, facilities for exporters, as well as, Import some raw materials, provided that they are not available similar within the Republic.

\section{Soft loans for projects that related in the crafts:}

Of course there is a great complaint of the loans profit and credit facilities for those who want to establish small projects related in the crafts. The previous organization can take a serious direction to these projects.

\section{Stimulation the role of the specialized technical faculties:}

Technical faculties and their departments that related in the crafts does not have a social role until now ,despite their presence in different governorates of the Republic .If the college provides their students by an incentive, for example, giving yearly performance scores for the students. 


\section{References:}

- $\quad$ Aldred, Cyril (1980) Egyptian Art in the Days of the Pharaohs.

- $\quad$ Andrews, Carol (1991) Ancient Egyptian Jewelry.

- Arnold, Dorothea (1999) When the Pyramids were Built.

- $\quad$ British Museum (1983). Egyptian Sculpture. By T.G.H. James and W.V. Davies.

- $\quad$ Friedman, Florence Dunn (1989) Beyond the Pharaohs: Egypt and the Copts in the 2nd to 7th Centuries A.D.

- $\quad$ Friedman, Florence Dunn, editor (1998) Gifts of the Nile: Ancient Egyptian Faience.

- $\quad$ Hall, Rosalind (1986) Egyptian Textiles. Shire Egyptology 4.

- $\quad$ Hope, Colin A. (1987) Egyptian Pottery. Shire Egyptology 5.

- $\quad$ James, T.G.H. (1986) Egyptian Painting and Drawing in the British Museum.

- $\quad$ Killen, Geoffrey (1994) Egyptian Woodworkers and Furniture.

- $\quad$ Killen, Geoffrey (1994) Egyptian Woodworking and Furniture. Shire Egyptology 21.

- $\quad$ Lesko, Barbara S. with Diana Wolfe Larkin and Leonard H. Lesko (1998) Joseph Lindon Smith: Paintings from Egypt. An Exhibition: Brown Univeristy, October 8 - November 21, 1998.

- $\quad$ Malek, Jaromir (1999) Egyptian Art.

- Metropolitan Museum of Art, New York (1999) Egyptian Art in the Age of the Pyramids.

- $\quad$ Michalowski, Kazimierz (1978) Great Sculpture of Ancient Egypt.

- Museum of Fine Arts, Boston (1982) Egypt's Golden Age: The Art of Living in the New Kingdom, 15581085 B.C. By Edward Brovarski, S. K. Doll and Rita E. Freed.

- $\quad$ Nicholson, Paul T. (1993) Egyptian Faience and Glass. Shire Egyptology 18.

- $\quad$ Robins, Gay (1986) Egyptian Painting and Reliefs. Shire Egyptology 3.

- $\quad$ Robins, Gay (1997) The Art of Ancient Egypt.

- $\quad$ Russmann, Edna R. (text) and David Finn (photographs) (1989) Egyptian Sculpture: Cairo and Luxor.

- $\quad$ Russmann, Edna R. (2001) Eternal Egypt: Masterpieces of Ancient Art from the British Museum.

- $\quad$ Scheel, Bernd (1989) Egyptian Metalworking and Tools. Shire Egyptology 13.

- Silverman, David P., editor (1997) Searching for Ancient Egypt: Art, Architecture and Artifacts.

- $\quad$ Smith, W. Stevenson (1998) The Art and Architecture of Ancient Egypt. 3rd edition. Revised by William Kelly Simpson.

- $\quad$ Tooley, Angela M. (1995) Egyptian Models and Scenes. Shire Egyptology 22.

- Vinson, Steve (1994) Egyptian Boats and Ships. Shire Egyptology 20.

Received: August 10, 2020

Accepted: October 08, 2020 